\title{
Phytoprotection
}

\section{Full-season and post-harvest applications of sterol-inhibiting fungicides to reduce ascospore formation in Venturia inaequalis}

\author{
A.R. Biggs et J. Warner
}

Volume 71, numéro 1, 1990

URI : https://id.erudit.org/iderudit/705977ar

DOI : https://doi.org/10.7202/705977ar

Aller au sommaire du numéro

Éditeur(s)

Société de protection des plantes du Québec (SPPQ)l

ISSN

0031-9511 (imprimé)

1710-1603 (numérique)

Découvrir la revue

Citer cet article

Biggs, A. \& Warner, J. (1990). Full-season and post-harvest applications of sterol-inhibiting fungicides to reduce ascospore formation in Venturia inaequalis. Phytoprotection, 71(1), 9-15. https://doi.org/10.7202/705977ar

\section{Résumé de l'article}

Nous avons évalué plusieurs fongicides inhibiteurs de stérols lors de programmes de vaporisation en pleine saison ou en post-récolte en vue de l'inhibition de la formation d'ascospores par le Venturia inaequalis, agent pathogène de la tavelure de la pomme. Les traitements post-récolte avec le flusilazole et le diniconazole étaient comparables ou supérieurs à ceux utilisant le benomyl, avec une suppression de la production d'ascospores de 55 à $99 \%$; cependant, le bitertanol a stimulé la production d'ascospores jusqu'à $52 \%$. Lorsqu'appliqués neuf fois lors des programmes en pleine saison, le bitertanol, le flusilazole et le triflumizole ont réduit la formation d'ascospores à un niveau similaire ou supérieur à celui obtenu avec le dodine. Les programmes en pleine saison ont été efficaces à réduire la production d'ascospores. 


\title{
Full-season and post-harvest applications of sterol-inhibiting fungicides to reduce ascospore formation in Venturia inaequalis
}

\author{
A.R. Biggs \\ Agriculture Canada, Research Station, \\ Vineland Station, Ontario, Canada LOR 2EO. \\ Current address: West Virginia University, University Experimental Farm, \\ P. O. Box 609, Kearneysville, WV 25430, U.S.A.
}

\author{
J. Warner \\ Agriculture Canada, Smithfield Experimental Farm, \\ P.O. Box 340, Trenton, Ontario, Canada K8V 5R5
}

(Received 1989-06-28; accepted 1989-11-06)

\begin{abstract}
Several sterol-inhibiting (SI) fungicides were tested in post-harvest and full-season spray programs for the inhibition of ascospore formation by Venturia inaequalis, the causal fungus of apple scab. Post-harvest treatments with flusilazole and diniconazole were comparable to or better than those with benomyl and suppressed ascospore production by 55 to $90 \%$, although bitertanol stimulated ascospore production by up to $52 \%$. When applied nine times in full-season programs, bitertanol, flusilazole, and triflumizole reduced ascospore formation to a degree similar to or greater than that achieved with dodine. Full-season programs with SI fungicides in combination with mancozeb were highly effective for reducing ascospore production.

Biggs, A. R., and J. Warner. 1990. Full-season and post-harvest applications of sterol-inhibiting fungicides to reduce ascospore formation in Venturia inaequalis. PHYTOPROTECTION 71: 9-15.

Nous avons évalué plusieurs fongicides inhibiteurs de stérols lors de programmes de vaporisation en pleine saison ou en post-récolte en vue de l'inhibition de la formation d'ascospores par le Venturia inaequalis, agent pathogène de la tavelure de la pomme. Les traitements post-récolte avec le flusilazole et le diniconazole étaient comparables ou supérieurs à ceux utilisant le benomyl, avec une suppression de la production d'ascospores de 55 à $99 \%$; cependant, le bitertanol a stimulé la production d'ascospores jusqu'à $52 \%$. Lorsqu'appliqués neuf fois lors des programmes en pleine saison, le bitertanol, le flusilazole et le triflumizole ont réduit la formation d'ascospores à un niveau similaire ou supérieur à celui obtenu avec le dodine. Les programmes en pleine saison ont été efficaces à réduire la production d'ascospores.
\end{abstract}

\section{Introduction}

Apple scab, caused by Venturia inaequalis (Cke.) Wint., is the most important disease affecting apples (Malus domestica Borkh.) in Ontario. The disease is usually controlled with protective fungicides in a full-season spray program. The use of sterol-inhibiting (SI) fungicides with superior activity against $V$. inaequalis has received great interest in recent years (Siegel 1981; Szkolnik 1981). Many of these materials have exhibited improved postinfection activity (Gupta and Kumar 1985; Gupta and Verma 1985; Kelley and Jones 1981; O'Leary and Sutton 1986; Szkolnik 1981 ) and pre-symptom activity (Kelley and Jones 1981; Szkolnik 1981) when compared

$0031-9511 / 90 \$ 1.00+.10$ to standard non-SI fungicides such as captan and mancozeb. Contradictory results on the post-symptom activity of SI fungicides have been reported (Biggs and Warner 1987; Gupta and Kumar 1985; Kelley and Jones 1981; Szkolnik 1981; Yoder and Hickey 1981), but, in general, SI fungicides are regarded as having only mediocre antisporulant activity.

In most apple growing regions, the fungus overwinters in leaves on the orchard floor. Pseudothecia develop and, in the spring, ascospores are discharged, initiating under the appropriate environmental conditions (Mills 1944), the disease on new foliage and fruit. It has been recognized for many years (Jehle and Cory 1924; Keitt and Palmiter 1937) that post-harvest sprays with eradicative activity could inhibit pseudothecial differentiation and ascospore formation, 
thereby allowing growers to be more successful with their early season protection programs (Conner and Heuberger 1968; Gadoury and MacHardy 1986). Phenyl mercuric chloride (Burchill and Hutton 1965) and benzimidazole fungicides (Ross 1973; Ross and Newbery 1975) have been used in some post-harvest programs, although problems with mammalian toxicity and fungicide resistance, respectively, have limited their usefulness (Schwabe 1982). The objective of our study was to examine the relative efficacy of several SI fungicides, used either in full-season programs or as post-harvest applications, to reduce ascosporic inoculum.

\section{Materials and methods}

Fungicides. The production of ascospores of $V$. inaequalis following fullseason and post-harvest applications of sterol-inhibiting fungicides was examined in 1986 and 1987 . The materials used in both years of the post-harvest experiment were benomyl (Benlate 50WP), bitertanol (Baycor 50WP), diniconazole (Spotless 25WP), and flusilazole (Nustar 20DF).

For the full-season application experiments in 1986, the materials were bitertanol, diniconazole, dodine (Cyprex 65WP), flusilazole, myclobutanil (Nova 40WP), and triflumizole (Procure 50WP).

In 1987, the materials were flusilazole, mancozeb (Manzate 200 80WP), myclobutanil (Systhane 60DF), hexaconazole (PP523 5SC), penconazole + mancozeb (Topas MZ 61WP), pyrifenox + mancozeb (ACR-3815 WP), flusilazole + mancozeb, myclobutanil + mancozeb, and hexaconazole + mancozeb. Fungicide treatments for use in the 1985 post-harvest dipping experiment included captan (Captan 50WP), benomyl, bitertanol, and flusilazole (Nustar 400 EC).

Full-season spray experiments. All experiments were conducted at Agriculture Canada, Smithfield Experimental Farm in Trenton, Ontario. The 1986 experiment was conducted on semi-dwarf apple trees cv. McIntosh. The orchard had been established in 1971 on MM.106 rootstock with trees spaced $3.0 \mathrm{~m} \times 5.0 \mathrm{~m}$. Six fungicide treatments (plus an unsprayed control) were replicated four times in a randomized complete block design with three trees per plot. Guard trees were located between plots to minimize spray drift. Fungicides were sprayed until runoff with a hydraulic handgun attached to a Rittenhouse plot sprayer operated at $2700 \mathrm{kPa}$. Nine fungicide sprays were applied at weekly intervals between 3 June and 1 August. On 6 October 1986, approximately 300 leaves with apple scab lesions were collected from the trees from each treatment. Leaves were placed in screened cages out of doors. The wooden cages used were $30 \mathrm{~cm} \times 30 \mathrm{~cm} \times 45 \mathrm{~cm}$ with $6.4 \mathrm{~mm}$ mesh screen on the bottom and 1.7 or $0.85 \mathrm{~mm}$ mesh screen on the sides and top.

The 1987 experiment was conducted on dwarf apple trees cv. McIntosh. The orchard had been established in 1971 on M.9 or M.26 rootstock with trees spaced $1.5 \mathrm{~m} \times 3.0 \mathrm{~m}$ and $3.0 \mathrm{~m}$ between plots. Nine fungicide treatments (plus an unsprayed control) were replicated three times in a randomized complete block design with three trees per plot. Guard trees were located between plots to minimize spray drift. Fungicides were applied on 29 April, 25 May, 15 and 25 June, and 6 July as described in 1986. On 9 October 1987, approximately 500 leaves were collected from each treatment, placed in screened cages, and stored out of doors as described in 1986.

In both years, percentage of terminal leaves with scab was assessed cluring the third week of August as described previously (Biggs and Warner 1987). All percentage data were converted to the arcsin transformation prior to analysis (Steel and Torrie 1980). The transformed data were subject to analysis of variance and means were separated with Duncan's multiple range test.

Post-harvest spray experiments. Trees used in these experiments were semi-dwarf McIntosh trees in the orchard previously described. The trees had received no previous fungicide sprays during the year of the experiment. Ninety-eight percent of the leaves were infected by $V$. inaequalis prior to treatments. In 1986, four fungicide treatments (plus an unsprayed control), repli- 
cated four times in a randomized complete block design with single-tree plots, were applied once on 1 October. This experiment was repeated in 1987 with a single postharvest spray applied to two trees per plot on 28 September. Additional plots received the first spray on 28 September followed by a second post-harvest spray applied on 5 October 1987. Non-sprayed control trees were included in both experiments. On 6 October 1986, and 13 October 1987, approximately 500 leaves were collected from each of the treatments and placed in cages as described previously.

Leaf sampling and ascospore determinations. In both years, control leaves were subsampled the following spring to determine the onset of ascospore maturity. Once this was determined, leaves in the cages representing the control and the fungicide treatments from the post-harvest and fullseason application experiments were subsampled five times on a 7- to 10-day schedule. The results are averaged over sampling time for each experiment.

For determinations of ascospore release, a subsample of 10 leaves per replicate was taken at random from each treatment and the leaves were soaked for $15 \mathrm{~min}$ in tap water at room temperature. The 10 leaves were positioned on a screen at the top of a spore discharge tower (Gilpatrick et al. 1972) and were subjected to an air flow of $50 \mathrm{~L} / \mathrm{min}$ for $10 \mathrm{~min}$. Released ascospores were impacted on vaseline-coated microscope slides and the numbers of ascospores in two 25-X compound microscope fields per slide from 10 slides per treatment were counted. Data from each of the four experiments were subjected to an analysis of variance and means separation procedures (Steel and Torrie 1980) for a randomized complete block design with collection dates as blocks.

A representative subsample of ascospores from each treatment was collected in water so that they could be tested for viability in a germination assay. Where possible, a minimum of 100 spores per treatment were examined. A spore was considered germinated if the germ tube was greater than one half of the length of the spore.

Additional data were collected on the effect of fungicides on the development of pseudothecia. Leaves from unsprayed trees were collected from the orchard floor and dipped in various fungicide suspensions on November 1985. Each fungicide suspension was prepared in $10 \mathrm{~L}$ of water and a minimum of 200 leaves per treatment were immersed in the fungicide suspension for about $15 \mathrm{~s}$, and allowed to drain for about $15 \mathrm{~s}$. Leaves were then placed into cages and allowed to air dry indoors for $24 \mathrm{~h}$. The cages were overwintered out of doors. Leaves were subsampled four times in the spring of 1986, and pseudothecia were crushed in water and examined under the compound microscope to determine their stage of development. Each of 20 pseudothecia per treatment was rated on a scale of 0 to 5 to describe the stage of ascus development: $0=$ undifferentiated asci; $1=$ asci present with cytoplasm; $2=$ asci present with immature ascospores; $3=$ mature ascospores present, none released; $4=$ mature ascospores present, some asci empty, and 5 = asci all empty, spores discharged. Maturity ratings of pseudothecia were analyzed with the non-parametric Kruskal-Wallis test (Steel and Torrie 1980). The numbers of pseudothecia on disks from treated leaves were determined also for the 1987 post-harvest experiment.

\section{Results and discussion}

Full-season spray program. In the 1986 experiment, leaves from trees treated with bitertanol exhibited the lowest numbers of ascospores the following spring, followed in effectiveness by dodine, flusilazole, and triflumizole which were similar (Table 1). Diniconazole and myclobutanil were less effective at reducing ascospore numbers. Ascospore reduction was greatest in the bitertanol treatment $(98 \%)$.

In the 1987 experiment, all fungicides were very effective at reducing ascospore numbers in May and June of the following year with all of the SI fungicides giving greater than $99 \%$ reductions (Table 2). Mancozeb alone reduced ascospores compared to the control (97\%) but was not as effective as the SI fungicides. Seasonal programs of hexaconazole + mancozeb and myclobutanil + mancozeb provided the greatest total reductions in ascospore numbers although these treatments could not be 
Table 1. Mean number of ascospores of Venturia inaequalis from apple leaf samples overwintered in cages following a full-season spray program with nine fungicide applications at weekly intervals between 3 June and 1 August $1986^{\S}$

\begin{tabular}{|c|c|c|c|c|}
\hline \multirow[b]{2}{*}{ Fungicide } & \multicolumn{2}{|c|}{$\begin{array}{c}\text { Dose } \\
(\mathrm{g} \text { a.i. } / 100 \mathrm{~L}) \\
\end{array}$} & \multirow{2}{*}{$\begin{array}{l}\text { Number of } \\
\text { ascospores }^{\dagger}\end{array}$} & \multirow{2}{*}{$\begin{array}{c}\text { Terminal leaves } \\
\text { with scab } \\
\text { on } 14 \text { August } 1986 \\
(\%)\end{array}$} \\
\hline & First spray & Other sprays & & \\
\hline Control & - & - & $50.5 \mathrm{a}^{\ddagger}$ & $97.1 \mathrm{a}$ \\
\hline Bitertanol & 15.0 & 7.5 & $0.9 \mathrm{~d}$ & $36.5 \mathrm{~b}$ \\
\hline Diniconazole & 1.5 & 1.5 & $17.2 \mathrm{~b}$ & $27.5 \mathrm{c}$ \\
\hline Dodine & 63.0 & 43.0 & $3.1 \mathrm{~cd}$ & $37.5 \mathrm{~b}$ \\
\hline Flusilazole & 2.4 & 1.8 & $3.1 \mathrm{~cd}$ & $21.1 \mathrm{c}$ \\
\hline Myclobutanil & 8.0 & 8.0 & $19.5 \mathrm{~b}$ & $26.6 \mathrm{c}$ \\
\hline Triflumizole & 16.6 & 12.5 & $10.0 \mathrm{c}$ & $27.0 \mathrm{c}$ \\
\hline
\end{tabular}

$\S$ Eighteen primary and secondary infection periods occurred between 20 April and 1 August 1986.

$\dagger$ Each value is the mean number of ascospores from 10025 -X microscope fields for all five subsampling dates.

$\ddagger$ Means with different letters in columns are significantly different according to Duncan's multiple range test $(P \leq 0.05)$.

separated statistically from the other SI fungicide or SI fungicide + mancozeb treatments. However, it is perhaps more important to examine the association between numbers of ascospores in the spring and the level of disease severity in the previous fall and note that penconazole + mancozeb, with a relatively high disease severity in the fall, also had similarly few ascospores in the spring (Table 2).

Post-harvest spray program. In the 1986 experiment, benomyl, diniconazole, and flusilazole reduced significantly $(P \leq 0.05)$ the numbers of ascospores released when compared with the control (Table 3). All resulted in $95 \%$ or greater reduction in ascospore numbers. More ascospores were collected from leaves treated with bitertanol than the unsprayed controls.

Leaves treated with bitertanol also released significantly $(P \leq 0.05)$ greater numbers of ascospores than the control leaves in the 1987 experiment. In the spring following one bitertanol post-harvest spray, increased numbers of ascospores were observed on all five collection dates. In the spring following two post-harvest sprays of bitertanol, increases in ascospore numbers

Table 2. Mean number of ascospores of Venturia inaequalis from apple leaf samples overwintered in cages following a full-season spray program in $1987^{\S}$

\begin{tabular}{lcrc}
\hline Fungicide & $\begin{array}{c}\text { Dose } \\
\text { (g.a.i./ / } 100 \mathrm{~L} \text { ) }\end{array}$ & $\begin{array}{c}\text { Terminal leaves } \\
\text { with scab } \\
\text { ascospores }\end{array}$ & $\begin{array}{c}\text { on } 19 \text { August } 1987 \\
\text { (\%) }\end{array}$ \\
\hline Control & - & $727.2 \mathrm{a}^{\ddagger}$ & $98.4 \mathrm{a}$ \\
Flusilazole & 0.6 & $2.2 \mathrm{c}$ & $6.4 \mathrm{f}$ \\
Flusilazole & 1.2 & $4.9 \mathrm{c}$ & $19.5 \mathrm{~d}$ \\
Flusilazole + mancozeb & $0.6+80$ & $2.6 \mathrm{c}$ & $14.0 \mathrm{de}$ \\
Hexaconazole $1+$ mancozeb & $0.9,0.6+80$ & $0.1 \mathrm{c}$ & $15.4 \mathrm{de}$ \\
Mancozeb & 80 & $18.0 \mathrm{~b}$ & $50.8 \mathrm{~b}$ \\
Myclobutanil & 3.0 & $0.4 \mathrm{c}$ & $11.0 \mathrm{ef}$ \\
Myclobutanil + mancozeb & $3.0+80$ & $0.1 \mathrm{c}$ & $7.8 \mathrm{ef}$ \\
Penconazole + mancozeb & $2.1+80$ & $0.3 \mathrm{c}$ & $31.7 \mathrm{c}$ \\
Pyrifenox + mancozeb & $3.9+80$ & $0.8 \mathrm{c}$ & $8.8 \mathrm{ef}$ \\
\hline
\end{tabular}

$\S$ Trees received sprays on 29 April; 25 May; 4, 15, and 25 June; and 6 July 1987.

$\dagger$ Each value is the mean number of ascospores from $10025-\mathrm{X}$ microscope fields for all five subsampling dates.

$\ddagger$ Means followed by different letters in columns are significantly different $(P \leq 0.05)$ according to Duncan's multiple range test.

I Hexaconazole was used alone at the higher rate up to apple bloom (one application) and starting at petal fall it was used at the lower rate in combination with mancozeb. 
were observed on three of five dates. Reductions in ascospore numbers were observed only once (two sprays, 24 May). These observations over two seasons contradicts previous reports of diminishing ascospore production with bitertanol (Gadoury and MacHardy 1984; Ross and Newbery 1981; Schwabe 1982).

Table 3. Mean number of ascospores of Venturia inaequalis from apple leaf samples overwintered in cages following one post-harvest fungicide application on 1 October $1986^{\S}$

\begin{tabular}{lcc}
\hline Fungicide & $\begin{array}{c}\text { Dose } \\
(\mathrm{g} \mathrm{a.i.} / 100 \mathrm{~L})\end{array}$ & $\begin{array}{c}\text { Number of } \\
\text { ascospores }^{\dagger}\end{array}$ \\
\hline Control & - & $62.9 \mathrm{~b}^{\ddagger}$ \\
Benomyl & 16.3 & $0.6 \mathrm{c}$ \\
Bitertanol & 7.5 & $89.1 \mathrm{a}$ \\
Diniconazole & 1.5 & $3.3 \mathrm{c}$ \\
Flusilazole & 1.8 & $3.2 \mathrm{c}$ \\
\hline
\end{tabular}

$\S$ Trees received no fungicide sprays during the season.

$\dagger$ Each value is the mean number of ascospores from $10025-\mathrm{X}$ microscope fields for all five subsampling dates.

$\ddagger$ Means followed by different letters within columns are significantly different $(P \leq 0.05)$ according to Duncan's multiple range test.

Leaves treated with diniconazole, flusilazole, and benomyl exhibited significant $(P \leq 0.05)$ reductions in numbers of ascospores (Table 4). Two post-harvest applications of flusilazole were the best treatment for reducing ascospore numbers $(98 \%)$, followed by one application of flusilazole $(88 \%)$. Benomyl and diniconazole were less effective in reducing ascospore numbers than flusilazole. Two applications of benomyl and diniconazole did not reduce spore release compared to one application of these fungicides. Germination of ascospores from pseudothecia receiving one postharvest fungicide application was uniformly greater than $90 \%$, although the numbers available for testing were very low from the flusilazole and benomyl treatments (less than 50).

One possible explanation for increased ascospore production in leaves treated with bitertanol is that our field population of $V$. inaequalis possessed a high proportion of isolates with resistance to bitertanol (Hildebrand et al. 1988). This hypothesis is supported by the relative inefficacy of bitertanol against $V$. inaequalis in the fullseason experiments. Late-season application of a fungicide to a population with low levels of fungicide resistance would favour the selection of a resistant subpopulation. Its presence would result in high numbers in the following spring. For this reason, the use of fungicides on populations with the potential to develop resistance should be limited to the early season. One alternative would be to combine the sterol-inhibiting fungicide with a broad-spectrum material such as mancozeb.

Table 4. Mean number of ascospores of Venturia inaequalis from apple leaf samples overwintered in cages following one or two postharvest fungicide applications on $28 \mathrm{Sep}$ tember and 5 October $1987^{\S}$

\begin{tabular}{|c|c|c|c|}
\hline Fungicide & $\begin{array}{l}\text { Number } \\
\text { of sprays }\end{array}$ & $\begin{array}{c}\text { Dose } \\
\text { (g a.i. } / 100 \mathrm{~L})\end{array}$ & $\begin{array}{l}\text { Number of } \\
\text { ascospores }^{\dagger}\end{array}$ \\
\hline ontrol & - & - & $73.2 \mathrm{c}^{\ddagger}$ \\
\hline & 1 & 16.3 & \\
\hline & 2 & & \\
\hline & 1 & & \\
\hline & 2 & & \\
\hline zole & 1 & & \\
\hline zole & 2 & & $\mathrm{de}$ \\
\hline & 1 & & \\
\hline lusilazole & 2 & & \\
\hline \multicolumn{4}{|c|}{$\begin{array}{l}\text { \$ Trees received no fungicide sprays during the } \\
\text { season. }\end{array}$} \\
\hline \multicolumn{4}{|c|}{$\begin{array}{l}\text { Each value is the mean number of ascospores from } \\
10025-\mathrm{X} \text { microscope fields for all five subsampling } \\
\text { dates. }\end{array}$} \\
\hline \multicolumn{4}{|c|}{$\begin{array}{l}\text { Means followed by different letters within columns } \\
\text { are significantly different }(P \leq 0.05) \text { according to } \\
\text { Duncan's multiple range test. }\end{array}$} \\
\hline
\end{tabular}

Resistance to bitertanol could explain ascospore numbers similar to the control, however this hypothesis does not adequately explain why increased numbers of ascospores were observed. One further possibility could be an inhibition by bitertanol of apple leaf saprophytes which compete with $V$. inaequalis for nutrients. With competition on the orchard floor inhibited, strains of $V$. inaequalis resistant to bitertanol could flourish. Additional research is required to determine if SI fungicides have any nontarget effects on leaf litter microorganisms.

Sterol-inhibiting fungicides have been shown to reduce the total numbers and the size of pseudothecia and to reduce significantly the numbers of ascospores during the 
primary infection season (Burchill and Hutton 1965; Gadoury and MacHardy 1984; O'Leary and Sutton 1986; Ross and Newbery 1981). In this study, reductions in the numbers of pseudothecia were observed in most treatments. All SI fungicide treatments except bitertanol and one application of diniconazole exhibited significantly $(P \leq 0.05)$ fewer pseudothecia relative to the control (Table 5).

Pseudothecial development was not inhibited by one post-harvest treatment with captan. However, benomyl, bitertanol, and flusilazole inhibited the maturation of pseudothecia (Table 6). Flusilazole at the higher rate was more effective than bitertanol, although mature ascospores were extremely rare in all of the fungicide treatments other than captan and the control.

Our study showed that seasonal programs of SI fungicides in combination with mancozeb substantially reduced the amounts of inoculum produced by overwintering apple leaves. When comparing the results of fullseason spray programs (Tables 1,2) and postharvest spray programs (Tables 3,4 ), post-harvest sprays alone are not a substitute for effective seasonal apple scab control programs. It is possible that significant reductions in the amount of overwintering inoculum, which affect disease incidence and severity, could be achieved without the need of post-harvest fungicide treatments.
Table 5. Mean number of pseudothecia from apple leaf samples overwintered in cages following one or two post-harvest fungicide applications on 28 September and 5 October $1987^{\S}$

\begin{tabular}{lccc}
\hline & $\begin{array}{c}\text { Number } \\
\text { of } \\
\text { sprays }\end{array}$ & $\begin{array}{c}\text { Dose } \\
\text { Fungicide }\end{array}$ & $\begin{array}{c}\text { Number } \\
\text { of pseu- } \\
\text { dothecia } \\
\text { per leaf } \\
\text { disk }^{\dagger}\end{array}$ \\
\hline Control & - & - & $104.4 \mathrm{a}^{\ddagger}$ \\
Benomyl & 1 & 16.3 & $28.4 \mathrm{~b}$ \\
Benomyl & 2 & 16.3 & $23.8 \mathrm{~b}$ \\
Bitertanol & 1 & 7.5 & $79.6 \mathrm{ab}$ \\
Bitertanol & 2 & 7.5 & $52.6 \mathrm{ab}$ \\
Diniconazole & 1 & 1.5 & $113.0 \mathrm{a}$ \\
Diniconazole & 2 & 1.5 & $22.6 \mathrm{~b}$ \\
Flusilazole & 1 & 1.8 & $16.0 \mathrm{~b}$ \\
Flusilazole & 2 & 1.8 & $30.2 \mathrm{~b}$ \\
\hline
\end{tabular}

$\S$ Trees received no fungicide sprays during the season.

† Mean number of pseudothecia from five 14-mm diameter leaf disks per fungicide treatment.

$\ddagger$ Means followed by different letters are significantly different $(P \leq 0.05)$ according to Fisher's LSD test.

Biggs, A. R., and J. Warner. 1987. Control of primary and secondary apple scab infections with sterol-inhibiting fungicides. Can. J. Plant Pathol. 9: 41-48.

Burchill, R. T., and K. E. Hutton. 1965. The suppression of ascospore production to facilitate the control of apple scab Venturia inaequalis (Cke.) Wint. Ann. Appl. Biol. 56: 285-292.

Conner, S. R., and J. W. Heuberger. 1968. Apple scab. V. Effect of late-season applications of fungicides on prevention of perithecial development by Venturia inaequalis. Plant Dis. Rep. 52: 654-658.

Table 6. Median maturity rating of pseudothecia of Venturia inaequalis from apple leaves after being dipped in various fungicide suspensions and overwintered in cages on 7 November $1985^{\S}$

\begin{tabular}{|c|c|c|c|c|c|}
\hline \multirow[b]{2}{*}{ Fungicide } & \multirow{2}{*}{$\begin{array}{c}\text { Dose } \\
(\mathrm{g} \text { a.i. } / \mathrm{L})\end{array}$} & \multicolumn{4}{|c|}{ Maturity rating in $1986^{\dagger}$} \\
\hline & & 28 April & 16 May & 29 May & 9 June \\
\hline Control & - & 1.0 & 1.0 & 3.0 & 3.0 \\
\hline Captan & 1.0 & 0 & 0 & 3.0 & 4.0 \\
\hline Benomyl & 0.16 & 0 & 0 & 0 & -1 \\
\hline Bitertanol & 0.075 & 0 & 0 & 0 & 0 \\
\hline Flusilazole & 0.009 & 0 & 0 & 0 & 0 \\
\hline Flusilazole & 0.018 & 0 & 0 & 0 & 0 \\
\hline$H$ value & & 21.9 & 9.8 & 63.0 & 56.2 \\
\hline
\end{tabular}

$\S$ Trees received no fungicide sprays during the season.

$\dagger$ Maturity rating of pseudothecia: $0=$ undifferentiated asci; $1=$ asci with cytoplasm; $2=$ asci with immature ascospores ; 3 = mature ascospores present, none released ; $4=$ mature ascospores present, some asci empty, and $5=$ asci empty, spores discharged. Each rating value is the mean of 20 observations.

$\ddagger$ An $H$ value of $>11.1$ indicates the significance of differences $(P \leq 0.05)$ among treatment medians according to the Kruskal-Wallis procedure.

I No pseudothecia were found in the treatment. 
Gadoury, D. M., and W. E. MacHardy. 1984. Suppression of ascocarp development by Baycor, Benlate and Vangard, 1983. Fungicide and Nematicide Tests 39: 10.

Gadoury, D. M., and W. E. MacHardy. 1986. Forecasting ascospore dose of Venturia inaequalis in commercial apple orchards. Phytopathology 76 : 112-118

Gilpatrick, J. D., C. A. Smith, and D. R. Blowers. 1972. A method of collecting ascospores of Venturia inaequalis for spore germination studies. Plant Dis. Rep. 56: 39-42.

Gupta, G. K., and J. Kumar. 1985. Studies on the curative (after infection) and eradicant (postsymptom) activity of fungicides against apple leaf infection by Venturia inaequalis. Pesticides 19: $18-20,25$.

Gupta, G. K., and K. D. Verma. 1985. Postsymptom antisporulant activity of fungicides on apple-scab foliage lesions. Indian J. Agric. Sci. 55: 381-382.

Hildebrand, P. D., C. L. Lockhart, R. J. Newbery, and R. G. Ross. 1988. Resistance of Venturia inaequalis to bitertanol and other demethylationinhibiting fungicides. Can. J. Plant Pathol. 10: 311-316.

Jehle, R. A., and E. N. Cory. 1924. Spraying experiments for the control of diseases and insects of the apple. Md. Agric. Exp. Stn. Bull. 262: 157-168.

Keitt, G. W., and D. H. Palmiter. 1937. Potentialities of eradicant fungicides for combatting apple scab and some other plant diseases. J. Agric. Res. 55: 397-437.

Kelley, R. D., and A. L. Jones. 1981. Evaluation of two triazole fungicides for postinfection control of apple scab. Phytopathology 71: 737-742.

Mills, W. D. 1944. Efficient use of sulfur dusts and sprays during rain to control apple scab. N. Y. Agric. Exp. Stn. (Ithaca) Ext. Bull. 630. 4 pp.
O'Leary, A. L., and T. B. Sutton. 1986. Effects of postinfection applications of ergosterol biosynthesis-inhibiting fungicides on lesion formation and pseudothecial development of Venturia inaequalis. Phytopathology 76: 119-124.

Ross, R. G. 1973. Suppression of perithecium formation in Venturia inaequalis by seasonal sprays of benomyl and thiophanate-methyl. Can. J. Plant Sci. 53: 601-602.

Ross, R.G., and R.J. Newbery. 1975.Effects of seasonal fungicide applications on perithecium formation and ascospore production in Venturia inaequalis. Can. J. Plant Sci. 55: 737-742.

Ross, R. G., and R. J. Newbery. 1981. Etfects of timing and number of sprays of benomyl, fenarimol and other fungicides on ascospore production in Venturia inaequalis. Can. J. Plant Pathol. 3: 173-176.

Schwabe, W. F. S. 1982. Baycor, effective for postharvest eradication of Venturia inaequalis. Pflanzenschutz-Nachr. 35: 125-133.

Siegel, M. R. 1981. Sterol-inhibiting fungicides: Effects on sterol biosynthesis and sites of action. Plant Dis. 6: 986-989.

Steel, R. G. D., and J. H. Torrie. 1980. Principles and procedures of statistics. $2^{\text {nd }}$ ed. McGraw-Hill Book Co., Toronto, Ontario. 633 pp.

Szkolnik, M. 1981. Physical modes of action of sterol-inhibiting fungicides against apple diseases. Plant Dis. 65: 981-985.

Yoder, K. S., and K. D. Hickey. 1981. Sterolinhibiting fungicides for control of certain diseases of apple in the Cumberland-Shenandoah region. Plant Dis. 65: 998-1001. 